\title{
SCIENTIFIC BASIS OF THE DEVELOPMENT OF THE BASIC ELEMENTS IN THE TECHNOLOGY OF SOYBEAN SOWING IN THE CONDITIONS OF FOREST-STEPPE OF UKRAINE
}

\section{Shevnikov M. Ya.}

\section{INTRODUCTION}

For the effective use of bioclimatic potential of natural and climatic conditions of unstable moistening of the Forest-Steppe of Ukraine, it is important to develop and introduce into the production of modern competitive technologies of cultivation of crops that ensure the maximum realization of their productive potential. In this regard, the research of the development of the basic elements of soybean cultivation technology, which would ensure high yields and would completely satisfy the Ukrainian market, is of particular relevance. Soybean production can become not only one of the important resources of protein and oil, but also an article of considerable financial income. This is convincingly evidenced by the much larger volumes of world production of soybeans and their trade and products of their processing than the volumes of production and sale of all other protein-oil crops combined.

Taking into consideration its leading position in the world agriculture, nitrogen-fixing ability, unique biological features, versatility of use, consistently high growth rates of production, value in eliminating vegetable protein and oil deficiency, use in industry, the soybean crops will increase. It is also important to keep in mind that modern varieties of this crop with high yield potential have emerged in production and require the development of effective technologies that would ensure the stabilization of the production of high quality soybean seeds. Soybean crops will increase as the potential of this crop is not fully understood. Other leguminous crops have, of course, an important role in some regions, but they only complement the soybeans in solving the protein problem. Due to the intensification of soybean production, the question arises as to the elements of 
cultivation technology that must ensure its high productivity. Among them are sowing period, method of sowing and seeding rate of soybeans. For soybeans, sowing time is of great importance, because it depends on the simultaneous germination, plant density, uniformity of ripening, size and quality of the crop. The rational placement of plants on the area to create optimal conditions for photosynthesis and the functioning of the root system is a subject of constant attention of researchers. It is noted that the soybean is characterized by the ability to change its productivity according to the area of nutrition, sowing method and depends, first of all, on the characteristics of the variety, meteorological conditions, as well as on the interaction of these factors. In recent years, there has been a tendency to narrow rows and increase plant density. Therefore, the question of the correct choice of sowing method and seeding rate should be addressed in relation to the variety and locality selected. These considerations were the basis for studying the terms, methods of sowing and sowing rates of soybeans in conditions of unstable moistening of the Forest-Steppe of Ukraine.

\section{Recommended parameters of economically valuable characteristics of soybean varieties for conditions of the left-bank Forest-Steppe of Ukraine}

Recently, the scientific literature indicates the feasibility of further progress in increasing crop yields by reducing the share of the empirical component in modern breeding practice. Breeders believe that in this regard, the tendencies of changing the complex of economic and valuable features in the process of sorting are important. The breeding work underwent significant changes in the architectonics of soybean plants. The ratio of the elements of the crop structure at different stages of the breeding work had a definite character. The growth and development of soybeans depended on the duration of the interphase periods. High-yielding soybean varieties have physiological features that influence the mechanism of plastic substance redistribution between plant organs. As a result of the analysis of the experimental material, the parameters of the model of soybean varieties with a yield potential of $4.5 \mathrm{t} / \mathrm{ha}$ are substantiated.

Soybean varieties, grown in Ukraine, are created for different soil and climatic zones and differ substantially from each other according to the requirements to environmental factors and economic and 
valuable indicators. Changing the area of cultivation in relation to the place of creation of soybean varieties in most cases negatively affects their productivity ${ }^{1,2}$.

The duration of the growing season is important as this indicator affects soybean productivity. New varieties must guarantee the achievement of optimal sowing time and minimal energy costs for seed drying ${ }^{3,4}$.

According to the breeders' research, the variety should be considered as a balanced system of displaying individual indicators and characteristics that are closely linked. A decrease or increase in one of them leads to a significant change in other indicators. The overall productivity of plants depends on the optimal combination of economically valuable traits in one variety. Studying the correlation between environmental conditions and the economic value of soybeans is of practical importance. There is a close relationship between the height of the attachment of the lower beans and the total yield of soybeans, which in most cases is associated with the loss of seed yield when harvested in a high cut. The data indicate that the later ripe variety, the effect of the attachment height of the lower beans is shown stronger ${ }^{5,6}$.

${ }^{1}$ Adamen F. F. (1994) Agroekologicheskoe obosnovanie sortovoy strukturyi soi [Agroecological substantiation of the soybean varietal structure]. Proceedings of Materials of the Republican Coordination and Methodological Council on the problem of the effective use of irrigated land for the cultivation and stabilization of the production of forages and feed proteins (Ukraine,Vinnitsya, August 17-18, 1994),Vinnitsya: Institute of forages UAAS, pp. 42-43. (in Russian)

${ }^{2}$ Babich A. O., Babich-Poberezhna A. A. (2008) Selektsiya i rozmischennya virobnitstva soyi $\mathrm{v}$ Ukrayini [Selection and placement of soybean production in Ukraine]. K.: FOP Danilyuk V.G., pp. 216. Monograph (in Ukrainian)

3 Zubets M.V. (2004) Naukovi osnovi agropromislovogo virobnitstva v zoni lisostepu Ukrayini [Scientific basis of agro-industrial production in the forest-steppe zone of Ukraine]. K.: Logos, pp. 776. (in Ukrainian)

4 Petr I., Chern V., Grushka L. (1984) Formirovanie urozhaya selskohozyaystvennyih kultur per. s bolgarskogo yaz. Blagoveschenskoy Z. K. [Formation of crop yield] M.: Kolos, pp. 367. (in Russian)

${ }^{5}$ Petrichenko V. F., Babich A.O. (2003) Naukovi osnovi suchasnih tehnologiy viroschuvannya visokobilkovih kultur [Scientific bases of modern technologies of cultivation of high protein crops]. Bulletin of agrarian science, pp. 15-19. (in Ukrainian)

${ }^{6}$ Shevnikov M.Ya. (2005) Svitovi agrotehnologiyi [World agrotechnology]. Poltava: Poltava, pp. 192. (in Ukrainian) 
The purpose of our research was to evaluate the soybean varieties for agricultural purposes in order to identify the most suitable for growing in the conditions of the left-bank Forest Steppe of Ukraine. The purpose of the research was to study the economically valuable characteristics of soybean varieties under different conditions of the growing season.

The productivity of agricultural crops in the region depends mainly on the conditions of moisture supply, since all other components of the agriculture system (species and varietal crop selection, tillage, fertilizer system, etc.) are evaluated, first of all, from the point of view of their impact on their accumulation, conservation and economical use of moisture. In order to identify the impact of individual environmental factors on soybean yield, it was found that the sum of effective temperatures in the conditions of the left-bank Forest Steppe is quite sufficient for the cultivation of early and middleripe soybean varieties. The more significant factor is the unstable and uneven soil moisture during the growing season.

Historical experience indicates that breeding for drought resistance in order to improve soybean productivity is a difficult task, and progress in this area is slow. Given the high variability of moisture conditions over time, in some years, the drought resistance of the variety is crucial, in others its potential productivity, resistance to lodging and disease. Such a list of problems in the practical implementation of soybean cultivation technology requires the study of the effects of drought, both on individual physiological processes and on the growth, development and productivity of soybean plants.

Growth of plants under tightly controlled conditions is required to identify the stress factor. But artificial simulation of stress regimes is significantly different from field conditions. This requires years of field research with a large number of arid and favorable years, which helps to identify the appropriate impact of soil moisture on the main indicators of productivity of soybean crops in comparison with the change in meteorological factors and the dynamics of soil moisture content. A significant increase in the aboveground mass of most crops is observed with the maximum use of solar energy, sufficient nutrition and water supply. Prolonged drought during the growing season of soybeans causes significant irreversible changes - the active leaf 
surface is intensively reduced, the leaves turn yellow and dry. Reducing the size of the photosynthetic apparatus accordingly reduces the synthesis of organic matter.

The characteristic of the water regime is determined by the flow of water into the soil and its use, i.e. water balance. If the formation of the vegetative mass of early spring crops mainly depends on autumnwinter and spring moisture reserves in the soil, then atmospheric precipitation during the growing season is important for the formation of the soybean crop. The researchers indicate the particular significance of the nature of the distribution of precipitation during the growing season: the closer this distribution to the needs in the critical period for plants, the more productive the water will be used for the formation of the harvest.

The weather conditions of the growing season significantly influenced the duration of the interphase periods. The varieties responded differently to a set of environmental factors. Relatively stable by this indicator varieties were selected. The main elements of seed productivity, as well as the overall seed yield, are more dependent on environmental conditions. Seed yield per plant depended, to a greater extent, on the height of the main stem, the number of fruiting nodes, beans and seeds on the plant. Late-ripening varieties showed a significant negative effect of the height of attachment of the lower beans on seed productivity.

The variety should have the following parameters of economic value:

- be resistant to low temperatures during germination and emergence of seedlings;

- be resistant to lack of moisture in the soil, high temperature and arid summer conditions;

- have a high intensity of growth and accumulation of aboveground mass at the beginning of the growing season with a view to rational use of spring moisture reserves and biological regulation of weed numbers;

- photosynthetic and symbiotic apparatus must be fully formed during the flowering period, and these two interrelated processes must function for a long period, allowing the generative organs to be fully 
provided with synthetic substances and readily available nitrogen compounds;

- it is necessary to increase the number of productive nodes of the main and lateral shoots, the proportion of three-seeded beans and the size of the seeds;

- reduce the gap between yields in different weather conditions by making varieties plastic.

Soybean varieties created for different soil and climatic zones differ substantially from one another to the requirements for environmental factors and economically valuable indicators. Changing the growing area in most cases adversely affects their productivity. The selection of soybean varieties for the conditions of the left-bank ForestSteppe of Ukraine should be carried out on the basis of many years of research, since the environmental conditions of different years have a significant impact on this indicator.

As a result of studying a large selection of soybean varieties, the most productive varieties of Sinara, Mentor, Kent, and Sigalia are selected, which in the conditions of the left-bank forest-steppe combine a short growing season and the main components of productivity (Table 1).

Based on the study of economically valuable features of regional and perspective varieties, we offer some practical indicators for modeling soybean varieties in the conditions of the left-bank Forest Steppe of Ukraine (Table 2). The determined productivity indicators allow the rational use of soil and climatic conditions, ensure high economic efficiency of cultivation.

The value of such economic features as the height of the plants, the height of the attached lower beans, the number of fruiting nodes, beans and seeds per plant, as well as the total mass of seeds from one plant, significantly depended on the environmental conditions. In the group of early-ripening varieties of plant height fluctuations ranged from 64.1 to $73.5 \mathrm{~cm}$, the middle-early varieties ranged from 90.8 to $114.2 \mathrm{~cm}$, the middle-ripened ones ranged from 64.1 to $118 \mathrm{~cm}$. An even greater variability in this trait was observed in the number of fruiting nodes, beans, and seeds per plant. The coefficient of variability of these features ranged from 15.5 to $43.0 \%$. 
Yield of soybean varieties in the conditions of the left-bank Forest Steppe of Ukraine

\begin{tabular}{|l|c|}
\hline \multicolumn{1}{|c|}{ Variety } & Yield, t/ha \\
\hline Cordoba & 2,55 \\
\hline Cardif & 2,75 \\
\hline Lisabon & 2,75 \\
\hline Kent & 3,33 \\
\hline Merlin & 2,35 \\
\hline Madison & 2,55 \\
\hline Larisa & 2,75 \\
\hline Diona & 2,16 \\
\hline Khutorianka & 2,55 \\
\hline Aligator & 2,35 \\
\hline Mentor & 2,94 \\
\hline Sultana & 2,75 \\
\hline Sinara & 3,14 \\
\hline Sigaliia & 3,92 \\
\hline Medeia & 1,57 \\
\hline SSD 0,5 & 0,08 \\
\hline
\end{tabular}

Table 2

Recommended parameters of economically valuable characteristics of soybean variety adapted to the conditions of the left-bank Forest-Steppe

\begin{tabular}{|l|l|l|}
\hline № & Characteristics & Indicator \\
\hline 1 & \multicolumn{1}{|c|}{2} & \multicolumn{1}{|c|}{3} \\
\hline 1. & Yield of seeds, t/ha & $2,5-3,0$ \\
\hline 2. & Plant height, cm & $70-75$ \\
\hline 3. & The number of branches on the plant, pcs. & $1,8-2,2$ \\
\hline 4. & Number of beans per plant, pcs. & $25-30$ \\
\hline 5. & Number of seeds per plant, pcs. & $50-60$ \\
\hline 6. & Number of seeds in beans, pcs. & $2,0-2,2$ \\
\hline 7. & Weight of 1000 seeds, $\mathrm{g}$ & $160-180$ \\
\hline 8. & Duration of vegetation, days & $110-120$ \\
\hline 9. & Height of attachment of the lower beans, cm & $15-17$ \\
\hline 10. & Resistance to lodging & High \\
\hline
\end{tabular}


End of Table 2

\begin{tabular}{|c|l|l|}
\hline 1 & \multicolumn{1}{|c|}{2} & \multicolumn{1}{|c|}{3} \\
\hline 11. & Collective index, $\%$ & $40-45$ \\
\hline 12. & Reaction to photoperiodism & Weak \\
\hline 13. & Drought resistance & High \\
\hline 14. & Nitrogen-fixing ability, mcg / plant / h & $20-30$ \\
\hline 15. & Growth type & Semi-determinant \\
\hline 16. & Protein content, $\%$ & $40-45$ \\
\hline 17. & Fat content, $\%$ & $20-25$ \\
\hline
\end{tabular}

Studying the correlation between environmental conditions and the economic value of soybeans is of practical importance. There is a close relationship between the height of the attachment of the lower beans and the total yield of soybeans, which in the most cases is associated with the loss of the seed harvest for harvesting in the high cut. The data indicate that the later ripe variety, the effect of the attachment height of the lower beans is shown stronger.

\section{Soybean productivity, depending on the timing, methods of sowing and sowing rates}

Due to the spread of new soybean varieties, the question arises as to the elements of cultivation technology that must ensure its high productivity. Of particular importance are the timing, methods of sowing and the rate of seeding of soybean seeds. Soybean, as a light-loving crop, forms a high yield only with the optimal nutrient density and density of plants, provided with moisture and nutrients, but the basic requirement is the best coverage of the leaf surface. As a light-loving crop, it forms a high yield only at the optimal for the specific variety of the area of nutrition and plant density, as well as with the appropriate structure of sowing. With the introduction into production of adapted early-ripe soybean varieties, there was a problem of providing a guaranteed annual formation of quality seed crop before the adverse to collect the conditions of the autumn period. The further spread of soybeans in conditions of unstable moistening of the left-bank part of the forest-steppe is constrained by insufficiently grounded zonal cultivation technology, especially in early sowing, where heat is a limiting factor. 
The question of the correct choice of sowing method and sowing standards should be solved in relation to the selected variety and terrain. In this regard, the rational use of heat resources in the early spring due to early sowing is of particular importance. These considerations are the basis for studying the methods of sowing and sowing rates of soybeans in conditions of unstable moistening of the left-bank part of the Forest-Steppe of Ukraine.

For soybeans, sowing time is crucial, because it depends on the quantity of the seedlings, plant density, uniformity of ripening, size and quality of the crop. The main criterion for the selection of the sowing period is the steady warming of the sowing soil. The minimum temperature for soybean seedlings is about $+10^{\circ} \mathrm{C}$ with a tendency to increase the soil temperature. Warming of the sowing layer to $+12-14^{\circ} \mathrm{C}$ ensures seed germination in the presence of moisture in it. When sowing seeds in an earlier period, it requires more time for germination, which increases the sharp damage to plants by diseases and pests, reduces the germination of seeds ${ }^{7}$.

Choosing the time of sowing, one should count on the full use of the vegetation period by plants, soil fertility, features of moisturizing the terrain, because the critical period for water consumption must fall to the flowering-forming phase of beans. The studies conducted in the Forest-Steppe zone of Ukraine indicate that the highest yields were obtained when sowing in the years with early spring in late April, in the years with late spring - in the first decade of May ${ }^{8,9}$.

The rational placement of plants in the area to create optimal conditions for photosynthesis and the functioning of the root system is a subject of constant attention of the researchers. It is noted that soy is characterized by the ability to change its productivity in accordance with the area of nutrition. Thus, no significant fluctuations in soybean

7 Adamen F.F., Vergunov V.A., Vergunova I.N. (2006) Agrobiologicheskie osobennosti vozdelyivaniya soi na Ukraine [Agrobiological features of soybean cultivation in Ukraine]. K.: Agrarna nauka, pp. 456. (in Russian)

${ }^{8}$ Babich A.O. (1996) Svitovi zemelni, prodovolchi i kormovi resursi [World's land, food and feed resources]. K.: Agrarna nauka, pp. 200. (in Ukrainian)

${ }^{9}$ Babich A.O. (1998) Soya dlya zdorov'yai zhittya na planeti Zemlya [Soybean for health and life on planet Earth]. K.: Agrarna nauka, pp.272. (in Ukrainian) 
seed yield with increasing row spacing from 15 to $60 \mathrm{~cm}^{10}$ were observed in the experiments at Kirovograd Institute of APV of UAAS. When choosing a method of sowing it is important to take into account the high plasticity of soybeans to the area of nutrition, which is manifested in the change of individual productivity of plants. In soybean crops with optimal density and area of plant nutrition, the main number of beans is formed on the main shoot, in the liquefied on the lateral branches. The negative effect of excessive thickening leads to premature yellowing and falling of leaves, incomplete use of light, moisture, nutrients, reduction of biological nitrogen fixation from the atmosphere ${ }^{11}$.

Increasing the rate of seeding from 400 to $1200 \mathrm{t} / \mathrm{ha}$ of plants led to a shortening of the growing season, significant plant elongation and reduced seed yields due to the formation of beans only at the top of the plants. In the thickened crops, soybeans were formed in the central and upper part of the stem, such plants quickly dropped leaves, intense lodging was observed and losses were lost during harvesting ${ }^{12}$.

Therefore, the row spacing depends on the ripening of the variety, the availability of sowing and harvesting equipment, soil fertility, moisture supply, the ability of plants to branch, the nature of the arrangement of leaves, the shape and height of plants. Late-ripe varieties, prone to lodging and branching, grow better at a smaller plant density, and early ripe varieties are more resistant to lodging and those that do not branch at greater plant density.

The aim of the research was to determine the optimum sowing density of soybeans by properly selecting the sowing rate and sowing method that would ensure optimal plant growth and development and

${ }^{10}$ Babich A.O., Petrinenko V.F., Adamen F.F. (1996) Problema fotosintezu i biologichnoyi fiksatsiyi azotu bobovimi kulturami [Problems of photosynthesis and biological fixation of nitrogen by legumes]. Bulletin of agrarian science, no 3, pp. 34-39. (in Ukrainian)

11 Babich A.O., Babich-Poberezhna A.A. (2008) Selektsiya i rozmischennya virobnitstva soyi $\mathrm{v}$ Ukrayini [Selection and placement of soybean production in Ukraine]. K.: FOP Danilyuk V.G., pp. 216. Monograph (in Ukrainian)

12 Grozdinskiy A.M. (1965) Allelopatiya v zhizni rasteniy i ih soobschestv [Allelopathy in the life of plants and their communities]. K.: Naukova dumka, pp. 200. Monograph (in Russian) 
high productivity. When determining the sowing period, it was taken into account that the early sowing period corresponds to the minimum soil temperature $\left(8-10^{\circ} \mathrm{C}\right)$ at which germination of soybean seeds is possible. The optimum sowing time was determined when the soil was heated to $+12-14{ }^{\circ} \mathrm{C}$. Late sowing period corresponded to increase in soil temperature to $16-18{ }^{\circ} \mathrm{C}$. In the first two cases, it is also necessary to take into account sufficient moisture supply of the topsoil. Late sowing was more often accompanied by low soil moisture. Meteorological conditions in the years of the experiments were diverse and fully characterized the climate of the area.

When growing soybeans are important not only performance indicators, but also a number of other characteristics of plant height and branching, the height of attachment of the lower beans, the tendency to lay down, the duration of the growing season. During the growth and development of plants, there was a constant change in the distribution of their underground and terrestrial organs in the horizontal and vertical directions, changing the volume of space and soil, depending on the size and configuration of the area of nutrition.

Important indicators that affect the size of the crop are the height of the plants and the height of attachment of the lower beans. The plant height varied under the influence of sowing method. In the continuous row sowing, the lowest plants were at sowing 500 thousand/ha of similar seeds $(57.3-63.4 \mathrm{~cm})$. Increase in the seeding rate contributed to the increase in plant height to $61,4-64,3 \mathrm{~cm}$ at sowing of 600 thousand/ha, $60,7-64,6 \mathrm{~cm}$ - at a seeding rate of 700 thousand/ha, $60,4-66,4 \mathrm{~cm}-$ at sowing 800 thousand/ha of similar seeds depending on the sort, term and method of sowing.

Plant density carried out a direct impact not only on plant height, but also on the height of the attachment of the lower beans, which largely determines the loss of harvest in mechanized harvesting. Changing the seeding rate from 500 to 800 thousand/ha of similar seeds in continuous row sowing helped to increase the attachment height of the lower beans from $11.7 \mathrm{~cm}$ to $15.7 \mathrm{~cm}$, with widerow sowing with spacing $45 \mathrm{~cm}$ - from $12.0 \mathrm{~cm}$ to $14,8 \mathrm{~cm}$ when sown in the third decade of April, respectively 12,2-15,7 and 11,4-15,3 - when sown in the first decade of May, $12,1-15,2 \mathrm{~cm}$ and $12,6-15,5 \mathrm{~cm}-$ when sown in the second decade of May. 
As a rule, in the liquefied crops in the lower tier of plants a considerable mass of the crop of seeds is formed, under their weight the branches lean towards the ground, causing losses during harvesting. In thickened crops fewer lateral shoots are smaller, but the stem is very thin, which contributes to the considerable lodging of plants.

The quantity of weeds of the crops depended on the time of sowing and pre-sowing of the soil. The number of weeds per $1 \mathrm{~m}^{2}$ during the germination was very varied: at early sowing within 287 374 , the optimum - 197-244, the late $-155-185$. Field germination differed with better performance at early $(64.8 \%)$ and optimal $(63.9 \%)$ sowing periods. With late sowing, the field germination decreased to $59.7 \%$, which is explained by the conditions of insufficient wetting of the topsoil (Table 3).

Table 3

Soybean seed yield and its structure depending on sowing period

\begin{tabular}{|l|l|c|c|c|}
\hline \multirow{2}{*}{ № } & \multicolumn{1}{|c|}{ Indicators } & \multicolumn{3}{|c|}{ Sowing period } \\
\cline { 3 - 5 } & & $\begin{array}{c}\text { early, } \\
18-24 \\
\text { April }\end{array}$ & $\begin{array}{c}\text { Optimal } \\
3-11 \\
\text { May }\end{array}$ & $\begin{array}{c}\text { late, } \\
16-24 \\
\text { May }\end{array}$ \\
\hline 1. & $\begin{array}{l}\text { Laboratory similarity } \\
\text { of seeds, \% }\end{array}$ & 97,6 & 97,6 & 97,6 \\
\hline 2. & Field germination of seeds, \% & 64,8 & 63,9 & 59,7 \\
\hline 3. & Height of plants, cm & 51,1 & 47,4 & 44,0 \\
\hline 4. & $\begin{array}{l}\text { Attachment height of the lower } \\
\text { beans, cm }\end{array}$ & 13,1 & 14,4 & 12,4 \\
\hline 5. & Number of beans per plant, pcs & 27,5 & 34,0 & 30,0 \\
\hline 6. & Number of seeds per plant, pcs & 50,7 & 55,0 & 53,8 \\
\hline 7. & Weight of seeds from 1 plant, g & 6,3 & 7,3 & 7,9 \\
\hline 8. & Weight of 1000 seeds, g & 123,8 & 134,0 & 133,8 \\
\hline 9. & Yield, t/ha & 1,90 & 2,11 & 2,01 \\
\hline
\end{tabular}

An analysis of plant height indicates its decrease when sowing soybeans at a later date. In early sowing it was 51.1 , in late $-44.4 \mathrm{~cm}$. The intermediate plant height $(47.4 \mathrm{~cm})$ was characteristic for the optimal sowing period from 3 to 11 May. The height of attachment of the lower beans was also highest at the optimum time $-14.4 \mathrm{~cm}$ then, 
at early sowing -13.1 , the late $-12.4 \mathrm{~cm}$. The weight of 1000 seeds in the areas of early sowing was $123.8 \mathrm{~g}$, the optimum -134.0 , the late $133.8 \mathrm{~g}$. of late - by $5 \%$.

In soybean cultivation technologies, the formation of a rational spatial structure of sowing is essential, which ensures a sufficiently uniform placement of the plants in the sowing. These measures significantly increase the competitiveness of soybean crops against weeds. The proposed indicators indicate greater expediency of sowing soybeans with row spacings of $45 \mathrm{~cm}$.

The value of the coefficient of competitiveness confirms that with increasing seeding rate soybean resistance to weeds were increased. The value of this coefficient at the sowing rate of 500-600 thousand/ha of similar seeds was 1.10-1.16 (ordinary row crop, $15 \mathrm{~cm}$ ). In welldeveloped crops with a higher rate of sowing of soybeans (700-800 thousand/ha of similar seeds), the coefficient of competitiveness was higher and was respectively $1.34-1.55$ and 1.61-2.00.

Analyzing the dependence of soybean yield on the number of weeds in different densities, we found that increasing the seeding rate helped to reduce weediness. When studying the indicators of relative decrease in soybean yield (in \% of control) it was found that at the seeding rate of $700-800$ thousand/ha of similar seeds, they are significantly higher than at 500-600 thousand/ha.

Investigating the effect of soybean sowing on weediness, we found a slight increase in row sowing. A more significant effect was increased in the rate of seeding of soybeans. There was a significant decrease in the number of weeds with increasing plant density. The indicators of the competitiveness of soybean crops and the harmfulness of weeds in these crops make it possible to properly assess the situation of the stability of cultivated plants in agrophytocenoses and to choose the appropriate methods of effective weed control. The criterion of reasonable application of herbicides should be a competitive relationship between cultural plants and weeds, which are of great importance for the establishment and use of ecological threshold of harmlessness.

In developed crops with a seeding rate of 700-800 thousand/ha of similar seeds, soybeans had a sufficiently high competitiveness for weeds. In areas with a natural weediness of its crops throughout the growing 
season, the growth and development of soybean plants was significantly sustainable and competed with weeds, ensuring high yields.

The soybeans are sensitive to changes in the size and shape of the area of plant nutrition in crops. In thickened crops soybean plants are extracted, have a thin stem with a small number of leaves, flowers and beans. The beans are formed at the top of the plants, resulting in low seed productivity. In liquefied sowing, soybean plants intensively branch with the formation of a large number of leaves, beans and seeds. In this case the individual productivity of plants is high, but the overall productivity of such sowing is reduced, in addition, with the liquefied placement of plants is characteristic close to the soil surface of the laying of beans, which causes significant losses of harvest during harvesting.

Plant height varied under the influence of sowing method. In continuous row sowing, the plants were the lowest when sowing 500 thousand/ha of similar seeds. With increasing seeding rate, there was an increase in plant height from $66.3 \mathrm{~cm}$ when sowing 600 thousand/ha of similar seeds, $69.1 \mathrm{~cm}-700$ thousand/ha to $73.5 \mathrm{~cm}$ when sowing 800 thousand/ha. Changing the seeding rate from 500 to 800 thousand/ha of similar seeds in the ordinary row sowing helped to increase the attachment height of the lower beans from 10.5 to $20.7 \mathrm{~cm}$, row sowing with rows $45 \mathrm{~cm}$ - from 12.4 to $20.1 \mathrm{~cm}$, tape sowing - from 12.3 to $19.3 \mathrm{~cm}$.

The seeding rate, more than the sowing method, affected the value of the soybean crop. The best conditions for the formation of crop yields were achieved when sowing 700 thousand/ha of similar seeds. Soybean yield at ordinary row sowing was $2.05 \mathrm{t} / \mathrm{ha}$, at wide-row sowing with spacing $45 \mathrm{~cm}-1.91 \mathrm{t} / \mathrm{ha}$, tape $-1.98 \mathrm{t} / \mathrm{ha}$. Increasing the rate of sowing to 800 thousand/ha of similar seeds did not contribute to a significant increase in yields, led to unnecessary costs of seeds and lodging of plants. Very low sowing rate of up to 500 thousand/ha - to decrease field germination of seeds, uneven seedlings, especially in the formation of soil peel and thinning of sowing (Table 4). Taking into account all these features, as well as organizational and economic factors and the impact of sowing on the elements of the structure of the crop, it is most advisable to sow soybean by ordinary row $(15 \mathrm{~cm})$ or wide row $(45 \mathrm{~cm})$ methods with a seeding rate of 700 thousand/ha of similar seeds. 
Table 4

Influence of sowing method and seeding rate on soybean yield

\begin{tabular}{|l|c|c|c|c|c|}
\hline \multirow{2}{*}{ Method of sowing } & $\begin{array}{c}\text { Seeding rate, } \\
\text { thousand/ha } \\
\text { of similar } \\
\text { seeds }\end{array}$ & 2011 & 2013 & 2014 & Average \\
\cline { 4 - 6 } & 500 & 1,93 & 0,97 & 2,03 & 1,64 \\
Ordinary row, & 600 & 2,07 & 1,12 & 2,54 & 1,91 \\
$15 \mathrm{~cm}$ & 700 & 2,08 & 1,20 & 2,88 & 2,05 \\
& 800 & 1,96 & 1,43 & 2,80 & 2,06 \\
\hline & 500 & 1,57 & 0,96 & 2,13 & 1,55 \\
Wide row, & 600 & 1,60 & 1,05 & 2,45 & 1,70 \\
with spacing 45 cm & 700 & 1,84 & 1,21 & 2,68 & 1,91 \\
& 800 & 1,91 & 0,90 & 2,60 & 1,80 \\
\hline & 500 & 1,66 & 0,89 & 2,12 & 1,56 \\
Tape sowing & 600 & 1,78 & 0,92 & 2,64 & 1,78 \\
method, 45x15cm & 700 & 2,11 & 1,07 & 2,75 & 1,98 \\
& 800 & 1,90 & 0,93 & 2,78 & 1,87 \\
\hline
\end{tabular}

The method and density of plant placement in the area depend, first of all, on the characteristics of the variety and the weather conditions, as well as on the interaction of these factors. Therefore, the question of the right choice of sowing method and seeding rate should be addressed in relation to the selected variety and soil and climatic conditions of the area.

\section{Soybean yield depending on the weather factors of the Forest-Steppe of Ukraine}

Most of the territory of Ukraine is characterized by favorable conditions for soybean cultivation, but even in relatively favorable areas it is periodically affected by extreme weather conditions. Therefore, the use of different agricultural measures is crucial in increasing the resistance of plants to different types of stressors. In agronomic terms, plant sustainability corresponds to the magnitude of the yield reduction under the influence of the environmental stress and is reflected by the magnitude of the productivity change. According to studies, at different tensions of the same extreme factor, the productivity of plants varies differently, so to compare the stability of 
species or varieties of plants, their assessment should be carried out in the same stress load ${ }^{13}$.

The formation of the commercial soybean crop, as well as other leguminous crops, is a very complicated process in comparison with other crops. This is due to the low property of regulating the number of productive shoots, as well as the slow and very prolonged differentiation of organs and a significant addiction of their development from environment conditions ${ }^{14,15}$.

The main components of yield of leguminous crops are: the number of plants per unit area, the number of productive stems, the number of beans per plant, or $1 \mathrm{~m}^{2}$ of space, the number of seeds in a bean in a plant, or $1 \mathrm{~m}^{2}$, a mass of seeds from plants, weight 1000 seeds. The dynamics of formation of these components of the yield proceeds in three phases: the main phase; maximum level phase; phase of quantitative reduction ${ }^{16}$. The number of productive shoots per unit area depends on the plant density and the extent of their branching. During vegetation period, under the influence of adverse factors (meteorological conditions, diseases, pests, competition), this indicator decreases significantly.

The main weather factors in the conditions of the Forest-Steppe of Ukraine, which adversely affect the productivity of soybeans in some years, are sharp fluctuations in temperature, uneven and insufficient rainfall during the growing season. According to Japanese researchers, even in the Tokachi area on island Hokkaido (Japan), 1.8-2.0 t/ha of

${ }^{13}$ Goto K., Yamatoto T. Studies on cool injury in bean plans. Part 3 Abromalieties in the reproductive processes relating to dropping as affect ted by cool temperatures before an thesis in soybean plants. - Res. Dropping as Bull. Hokkaido Nat. Agr. exp. St., 1972. - 100:14.

${ }^{14}$ Kaminskiy V.F. (2000) Stan ta perspektivi virobnitstva gorohu v Ukrayini [The state and prospects of pea production in Ukraine]. Bulletin of agrarian science, no 9, pp. 22-25. (in Ukrainian)

15 Titov A.F., Drozdov S.N., Anenkova T.V. (1987) Issledovanie reaktsii rasteniy soi na deystvie temperaturyi. Granitsyi temperaturnyih [Study of the reaction of soybean plants to the effect of temperature. The boundaries of the temperature zones]. Plant physiology, no 2, pp. 350-355. (in Russian)

${ }^{16}$ Shevnikov M.Ya. (2003) Umovi zovnishnogo seredovischa ta produktivnist soyi i gorohu v livoberezhnomu lisostepu Ukrayini[Environmental conditions and productivity of soybeans and peas in the left-bank Forest Steppe of Ukraine]. Bulletin of Poltava State Agrarian Academy, no 6, pp. 8-10. (in Ukrainian) 
soybean grain were obtained in temperature favorable years, and in unfavorable years the yield decreased 3-5 times. This decline in productivity was associated with a decrease in the number of beans and seeds, harvest index, plant height and number of nodes.

Many studies indicate that, depending on the variety and cultivation area, the sum of active temperatures for soybeans is $1700-3200{ }^{\circ} \mathrm{C}$. It is most demanding for heat during the sprouting period, flowering and bean formation. The biological minimum for the flowering of most varieties is $16-18{ }^{\circ} \mathrm{C}$. In the experiments during growing soybeans at a constant temperature of $+15^{\circ} \mathrm{C}$, the beans were practically not formed on the plants. The increase in temperature had a positive effect on the fruit formation ${ }^{17,18}$.

In many cases, the effectiveness of a variety of plants is judged only by the absolute value of its yield under favorable conditions of cultivation. But this is not entirely true, because this estimate does not take into account the degree of change in the potential productivity of the variety under the influence of stress, that is, a measure of plant stability. In order to compare the productivity of different types of crops or varieties, one should focus on their relative resistance to environmental conditions ${ }^{19}$.

The technology of growing crops is the result not only of a deep knowledge of the patterns of growth and development of plants, but also the ability to most use them in specific conditions of climatic potential. All these measures should be implemented taking into account the climatic resources of the specific area ${ }^{20}$.

The most common leguminous crop for a long period in the forest-steppe zone was peas, which occupied large acreage. For the past ten years, soy has squeezed peas and occupied a large area.

17 Sinyagin I.I. (1966) Ploschadi pitaniya rasteniy [Area of plant nutrition] M.: Rosselhozizdat, pp. 10-24. Monograph (in Russian)

${ }^{18}$ Sichkar V.I. (1984) O holodostoykosti rasteniy soi [About cold resistance of soybean plants]. Agricultural biology. no 4, pp. 11-16. (in Russian)

${ }^{19}$ Nguen Thi Chi., Andreeva T.F., Stroganova L.E. (1983) Fotosintez i fiksatsiya atmosfernogo azota rasteniyami soi [Photosynthesis and fixation of atmospheric nitrogen by soybean plants]. Fiziologiya rasteniy. no 4, pp. 674-671. (in Russian)

${ }^{20}$ Matushkin V.O., Magomedov R.A., Moshkova O.M. (2006) Sorti soyi i yih biologichni osoblivosti viroschuvannya [Soybean varieties and their biological features of cultivation]. Kharkiv, pp. 56 Monograph (in Ukrainian) 
An example of farms in Poltava region showed that pea crops in the last 20 years have decreased by 5-6 times. For example, the area of sowing of this crop in the period 1985-1994 was in the range of 100.1 to 117.4 ha. Since 1985 , its acreage has tended to decline, especially since 2000 to the present time it has decreased by 5 times, the acreage of peas has stabilized at the level of 19.7-25.4 thousand hectares. The sharp fluctuations in weather conditions, especially the rather uneven distribution of rainfall, caused unstable soil moisture during the growing season.

The expediency of soybean cultivation in the farms of the Poltava region has been reflected in the dynamics of acreage over the past 20 years. Significant variations in the area of sowing of soybeans in different years are characteristic. Its largest acreage was in two periods: the first - 1988-1991, it ranged from 9052 to 19090 hectares; the second - 2000-2007, with an area of 121568 hectares in 2006, which is 12 times more than in 2000. For the implementation of the program of further expansion of soybean crops in the following years, it stabilized within 140-180 thousand hectares.

The creative use of modern technology of cultivation, taking into account the soil and climatic conditions, the level of crop culture and biological characteristics of crops allowed to get high yields of soybeans. During the years of the study of fluctuations in the yield of soybean seeds, the average in the Poltava region ranges from 0.56 to $1.65 \mathrm{t} / \mathrm{ha}$. The average statistical yield of soybeans over 20 years is $1.25 \mathrm{t} / \mathrm{ha}$.

An important source of oil is sunflower. However, the area of this crop is over-enlarged and does not meet the agrotechnical requirements of crop rotation. In many agricultural enterprises, the proportion of sunflower is more than $20 \%$ of the total acreage, which adversely affects the phytosanitary status of the fields and the economy of the economy. Rapeseed occupies relatively small acreage with a tendency to increase in subsequent years.

The Poltava region has a long and rich history of introduction, selection and cultivation of soybeans in Ukraine. It has been one of the largest producers of this valuable culture in the country for the last ten years. This happened due to the introduction into production of new generation of soybean varieties and mastering of the varietal technology of their cultivation. 
We have also analyzed the yields of soybean and pea seeds over the past 14 years, and in parallel - soil moisture, rainfall and average daily air temperature during the growing season. The statistical dependence between the yield levels of these crops and the indicators of natural resource efficiency each year had some relationship. The results of statistical studies have shown significant fluctuations in the yields of both crops over the years. The average statistical yield for the years of research was $1.85 \mathrm{t} / \mathrm{ha}$; peas $-2.70 \mathrm{t} / \mathrm{ha}$.

The purpose of our research was to study the influence of external environmental factors on the productivity of soybeans and peas in the conditions of the left-bank part of the forest-steppe. Soybean yields were studied and maximum and minimum crop yields identified in the study. It was respectively 3.51 and 0.65 t/ha and the probability of its recurrence was found. To determine the level of reliability of repetition of different yield levels, depending on the agrometeorological conditions of the zone of non-sustainable wetting of the forest-steppe of Ukraine, over the years, was conventionally divided the resulting yield into five subsequent levels with intervals of $0.5 \mathrm{t}$. Soybean yield over the years of field research ranged from 0.61 to $3.51 \mathrm{t} / \mathrm{ha}$, peas from 1.51 to $4.20 \mathrm{t} / \mathrm{ha}$.

In the process of further analysis, the effect of air temperature and rainfall were studied to identify the effects of specific agrometeorological factors on soybean yield. Taking into account that the sum of active temperatures (above $+10{ }^{\circ} \mathrm{C}$ ) in the conditions of the left-bank part of the forest-steppe is $2600-3000{ }^{\circ} \mathrm{C}$, we consider it quite sufficient for the cultivation of early and middle-ripe soybean varieties. A more substantial factor is soil moisturizing, because it has significant fluctuations in rainfall, especially during the growing season of field crops (table. 5). Analyzing the level of soybean yield on the average over the years of research, we point out its significant difference in different years. The most likely yield was in the range of 1.5-2.0 t/ha, which was observed for 4 years out of 10. The soil and climatic conditions of unstable moisture zone are also favorable for obtaining soybean yield within 2.0-2.5 t/ha, observed in $26 \%$ of studied years, or 3 years from 10 . The probability of obtaining soybean yield in the range of 1.0-1.5 t/ha, as well as the yield above $2.5 \mathrm{t} / \mathrm{ha}$, is $13 \%$. 
Droughts that have become characteristic of the climatic conditions of unstable moisturizing especially cause a negative effect in the spring. Pea seedlings do not always have a satisfactory condition or there is a significant lack of moisture during critical water useof pea. Therefore, as the results of the study showed, it is not possible to predict the exact probability of harvesting peas in different years. The statistical correlation between pea yield levels and natural resource efficiency indicators each year was in the range of $10-15 \%$ and no statistical regularities could be detected.

Table 5

Statistical analysis of the probable yield of soybeans in the conditions of unstable moistening of the left-bank part of the forest-steppe (average for 2000-2015)

\begin{tabular}{|c|c|c|c|}
\hline \multicolumn{2}{|c|}{ Soybean } & \multicolumn{2}{c|}{ Peas } \\
\hline Yield level, & $\begin{array}{c}\text { The probability } \\
\text { of recurring } \\
\text { yields } \\
\text { by years, } \%\end{array}$ & $\begin{array}{c}\text { Yield level, } \\
\text { t/ha }\end{array}$ & $\begin{array}{c}\text { The probability } \\
\text { of recurring } \\
\text { yields by } \\
\text { years, } \%\end{array}$ \\
\hline $0,51-1,00$ & 8 & Less 2,00 & 22 \\
\hline $1,01-1,50$ & 13 & $2,01-2,50$ & 26 \\
\hline $1,51-2,00$ & 40 & $2,51-3,00$ & 22 \\
\hline $2,01-2,50$ & 26 & $3,01-3,50$ & 10 \\
\hline 2,51 and more & 13 & 3,51 and more & 20 \\
\hline
\end{tabular}

Analyzing soil moisture during the growing season of both crops, we can point out the close relationship between the amount of rainfall in the first (May-June) and the second (July-August) half of the growing season and their yield. In order to identify the specific impact of uneven rainfall during the growing season, the rainfall coefficient was determined. Conditionally divided the growing season into 2 parts the first part - May-June, the second - July-August.

The values of the precipitation distribution coefficient were determined by dividing the rainfall of the first part of the growing season by the rainfall of the second part of it. For example, in 2009, the total rainfall in the first half of the growing season was $129.1 \mathrm{~mm}$, in the second half $-42.9 \mathrm{~mm}$. The precipitation distribution coefficient was $129.1 / 42.9=3.01$. The values of the coefficients for other years of 
research were similarly determined. The fluctuations in the magnitude of this coefficient ranged from 0.26 to 3.10 , i.e. if this indicator was smaller, the less precipitation was observed in the first half of the growing season and the greater rainfall in the second (July-August).

For reliability of the results of the study, the rainfall distribution coefficients were grouped into two groups of $0.2-2.0$ and 2.1-3.1 for which the average seed yield was determined. This made it possible to reveal the nature of the influence of precipitation distribution on soybean and pea yields (Table 6).

Table 6

Yield of soybeans and peas depending on the nature of the distribution of rainfall of the first and second part of the growing season (average for 2000-2015)

\begin{tabular}{|c|c|c|}
\hline Culture & Precipitation coefficient & Yield, t/ha \\
\hline \multirow{2}{*}{ Soybean } & $0,2-2,0$ & 1,79 \\
& $2,1-3,1$ & 1,28 \\
\hline \multirow{2}{*}{ Peas } & $0,2-2,0$ & 2,66 \\
& $2,1-3,1$ & 3,41 \\
\hline
\end{tabular}

It is established that under the conditions of better moisture supply of the soil of the first half of the growing season (May-June) peas provides stable and high yield of grain, i.e. if the value of distribution coefficient of precipitation is $2.1-3.1$, yields peas will be high (3.41 t/ha). In the absence of rainfall during this period, the yield of peas sharply decreases. The yield decreased by $2.66 \mathrm{t} / \mathrm{ha}$ by a factor of $0.2-2.0$.

The nature of the formation of soybean yield is sharply opposite to the distribution of rainfall typical for peas. Higher rainfall in the second half of the growing season (July - August) can provide consistently high soybean yields. With a value of rainfall coefficient in the range of 0.2-2.0, soybean yield will always be high $-1.79 \mathrm{t} / \mathrm{ha}$, and, conversely, if the coefficient index is $2.1-3.1$, then the yield will always be low $-1.28 \mathrm{t} / \mathrm{ha}$.

\section{CONCLUSIONS}

In order to grow soybeans, it is necessary to pay attention to the meteorological factors of the area and its biological requirements, which will contribute to obtaining high crop yields. For the growth and 
the development of plants, the formation of the crop requires three main factors, they are: light, heat, moisture. The most variable of them is moisture and heat. The main limiting factor for high productivity of soybeans is the moisture content of the area. In most cases, the sum of effective temperatures for early and mid-early soybean varieties is sufficient to generate high soybean yields.

In the conditions of better moisture supply of soil in May-June, it is more likely to count on the high yield of peas and, conversely, for the uniform distribution of precipitation, and even better their number in July-August, you can count on the high soybean yield. Therefore, these two cultures must be mandatory farms in the left-bank part of the forest for greater probability of stable harvest of grain and protein. Taking into account the weather conditions of the territory of the natural zone will allow in each case to differentiate the development of agrotechnical measures to improve the crop culture and obtain a stable crop yields.

When choosing the period of sowing of soybeans, one should take into account the temperature level and moisture of seed soil layer. Early sowing plants (third decade of April) had a longer growing season than late-sowing plants. With insufficient supply of moist soil and elevated air temperature, the growing season was shortened by 7-12 days. Changing the sowing rate from 500 to 800 thousand/ha of similar seeds helped to increase the attachment height of the lower beans from 10.5 to $16.7 \mathrm{~cm}$. The best conditions for the formation of the crop were formed when sowing 700 thousand/ha of similar seeds. Soybean yield in the row sowing method was $-2.05 \mathrm{t} / \mathrm{ha}$, wide-row spacing $45 \mathrm{~cm}-1.91$, tape $-1.98 \mathrm{t} / \mathrm{ha}$. Considering the influence of sowing method and sowing rate on the elements of the crop structure, it is most expedient to sow soybeans in the usual row way $(15 \mathrm{~cm})$ or wide-row way $(45 \mathrm{~cm})$ with a sowing rate of 700 thousand/ha.

\section{SUMMARY}

According to the results of the study of soybean varieties, the most productive varieties are selected, which in the conditions of the left-bank forest-steppe combine a short period of vegetation and the main components of productivity. The weather conditions of the growing season significantly influenced the duration of the interphase periods. Seed yields from one plant depended on the height of the main 
stem, the number of fruiting nodes, beans and seeds on the plant. Lateripening varieties exhibited a negative influence of the height of attachment of the lower beans on seed productivity.

The soybean sowing time depends on the germination, the density of the plants, the uniformity of ripening, the size and quality of the crop. The main criterion for the selection of the sowing period is the steady warming of the sowing soil. The minimum temperature for soybean seedlings is about $+10^{\circ} \mathrm{C}$, if it has further increase in soil temperature. Warming up the seedbed to $+12-14^{\circ} \mathrm{C}$ ensures seed germination in the presence of moisture. The optimum sowing period for soybeans is the first half of May. Under these conditions, you can expect maximum yields. Early or late sowing reduces the yield of soybean seeds by $12-14 \%$.

Changing the sowing rate from 500 to 800 thousand/ha of similar seeds helped to increase the attachment height of the lower beans from 10.5 to $16.7 \mathrm{~cm}$. The best conditions for the formation of the crop were formed when sowing 700 thousand/ha of similar seeds. Soybean yield for row sowing was $2.05 \mathrm{t} / \mathrm{ha}$, for wide-row sowing with spacing $45 \mathrm{~cm}-1.91$, for tape sowing $-1.98 \mathrm{t} / \mathrm{ha}$. Considering the influence of the sowing method and the seeding rate on the elements of the crop structure, it is most expedient to sow soybeans in the usual row way $(15 \mathrm{~cm})$ or wide-row sowing $(45 \mathrm{~cm})$ with a seeding rate of 700 thousand/ha.

\section{REFERENCES}

1. Adamen F. F. (1994) Agroekologicheskoe obosnovanie sortovoy strukturyi soi [Agroecological substantiation of the soybean varietal structure]. Proceedings of Materials of the Republican Coordination and Methodological Council on the problem of the effective use of irrigated land for the cultivation and stabilization of the production of forages and feed proteins (Ukraine,Vinnitsya, August 17-18, 1994), Vinnitsya: Institute of forages UAAS, pp. 42-43. (in Russian)

2. Babich A. O., Babich-Poberezhna A. A. (2008) Selektsiya i rozmischennya virobnitstva soyi v Ukrayini [Selection and placement of soybean production in Ukraine]. K.: FOP Danilyuk V.G., pp. 216. Monograph (in Ukrainian) 
3. Zubets M. V. (2004) Naukovi osnovi agropromislovogo virobnitstva $\mathrm{v}$ zoni lisostepu Ukrayini [Scientific basis of agroindustrial production in the forest-steppe zone of Ukraine]. K.: Logos, pp. 776. (in Ukrainian)

4. Petr I., Chern V., Grushka L. (1984) Formirovanie urozhaya selskohozyaystvennyih kultur per. s bolgarskogo yaz. Blagoveschenskoy Z. K. [Formation of crop yield] M.: Kolos, pp. 367. (in Russian)

5. Petrichenko V. F., Babich A.O. (2003) Naukovi osnovi suchasnih tehnologiy viroschuvannya visokobilkovih kultur [Scientific bases of modern technologies of cultivation of high protein crops]. Bulletin of agrarian science, pp. 15-19. (in Ukrainian)

6. Shevnikov M. Ya. (2005) Svitovi agrotehnologiyi [World agrotechnology]. Poltava: Poltava, pp. 192. (in Ukrainian)

7. Adamen F. F., Vergunov V. A., Vergunova I. N. (2006) Agrobiologicheskie osobennosti vozdelyivaniya soi na Ukraine [Agrobiological features of soybean cultivation in Ukraine]. K.: Agrarna nauka, pp. 456. (in Russian)

8. Babich A. O. (1996) Svitovi zemelni, prodovolchi i kormovi resursi [World's land, food and feed resources]. K.: Agrarna nauka, pp. 200. (in Ukrainian)

9. Babich A. O. (1998) Soya dlya zdorov'yai zhittya na planeti Zemlya [Soybean for health and life on planet Earth]. K.: Agrarna nauka, pp. 272. (in Ukrainian)

10. Babich A. O., Petrinenko V.F., Adamen F.F. (1996) Problema fotosintezu i biologichnoyi fiksatsiyi azotu bobovimi kulturami [Problems of photosynthesis and biological fixation of nitrogen by legumes]. Bulletin of agrarian science, no 3, pp. 34-39. (in Ukrainian)

11. Babich A. O. (2000) Produktivniy potentsial sortiv soyi dlya regioniv Ukrayini [Productive potential of soybean varieties for the regions of Ukraine]. Propozitsiya. no 11, pp. 33-35. (in Ukrainian)

12. Grozdinskiy A. M. (1965) Allelopatiya v zhizni rasteniy i ih soobschestv [Allelopathy in the life of plants and their communities]. K.: Naukova dumka, pp. 200. Monograph (in Russian)

13. Goto K., Yamatoto T. Studies on cool injury in bean plans. Part 3 Abromalieties in the reproductive processes relating to dropping as affect ted by cool temperatures before an thesis in soybean plants. Res. Dropping as Bull. Hokkaido Nat. Agr. exp. St., 1972. - 100:14. 
14. Kaminskiy V. F. (2000) Stan ta perspektivi virobnitstva gorohu $\mathrm{v}$ Ukrayini [The state and prospects of pea production in Ukraine]. Bulletin of agrarian science, no 9, pp. 22-25. (in Ukrainian)

15. Titov A. F., Drozdov S. N., Anenkova T. V. (1987) Issledovanie reaktsii rasteniy soi na deystvie temperaturyi. Granitsyi temperaturnyih [Study of the reaction of soybean plants to the effect of temperature. The boundaries of the temperature zones]. Plant physiology, no 2, pp. 350-355. (in Russian)

16. Shevnikov M. Ya. (2003) Umovi zovnishnogo seredovischa ta produktivnist soyi i gorohu v livoberezhnomu lisostepu Ukrayini [Environmental conditions and productivity of soybeans and peas in the left-bank Forest Steppe of Ukraine]. Bulletin of Poltava State Agrarian Academy, no 6, pp. 8-10. (in Ukrainian)

17. Sinyagin I. I. (1966) Ploschadi pitaniya rasteniy [Area of plant nutrition] M.: Rosselhozizdat, pp. 10-24. Monograph (in Russian)

18. Sichkar V. I. (1984) O holodostoykosti rasteniy soi [About cold resistance of soybean plants]. Agricultural biology. no 4, pp. 1116. (in Russian)

19. Nguen Thi Chi., Andreeva T. F., Stroganova L. E. (1983) Fotosintez i fiksatsiya atmosfernogo azota rasteniyami soi [Photosynthesis and fixation of atmospheric nitrogen by soybean plants]. Fiziologiya rasteniy. no 4, pp. 674-671. (in Russian)

20. Matushkin V. O., Magomedov R. A., Moshkova O. M. (2006) Sorti soyi i yih biologichni osoblivosti viroschuvannya [Soybean varieties and their biological features of cultivation]. Kharkiv, pp. 56 Monograph (in Ukrainian)

\section{Information about the author:} Shevnikov M. Ya., Doctor of Agricultural Sciences, Professor, Professor at the Department of Plant Growing,

Poltava Statev Agrarian Academy 1/3, Skovoroda str., Poltava, 36003, Ukraine ORCID 0000-0003-0810-523X 